\title{
Introducing TOCSE: A Tool to Bridge Didactic Learning to Clinical Application $\$$
}

\author{
Leilani B. Mercado-Asis, M.D., Ph.D., MPH
}

Keywords TOCSE, SOAP, progress notes, discharge summary

\section{TARGET-ORIENTED CLINICAL SKILL EN- HANCEMENT (TOCSE): PART 2}

Part 2 of TOCSE is geared towards $3^{\text {rd }}$ year medical students preparing to be in the $4^{\text {th }}$ year. It has the following important elements as follows:

- Identifying clinical problems as targets to resolve.

- Writing daily progress notes through S-O-A-P.

- Writing the Assessment.

- Formulating Plans according to assessment.

- Constructing the TOCSE table.

- Writing the Discharge Summary.

\section{QUALIFIERS FOR CLINICAL SITUATIONS}

Table 1 shows the qualifiers to describe clinical situations in progress notes.

\section{WRITING DAILY PROGRESS NOTES}

Progress notes are a part of the medical record that accounts for a patient's course. It serves as a basis for planning patient care, documenting communication

Prof. Leilani B. Mercado-Asis

lanibmasis@gmail.com

1 Faculty of Medicine and Surgery, University of Santo Tomas, Manila, Philippines

\begin{tabular}{ll}
\hline \multicolumn{2}{l}{ Table 1. Qualifiers for clinical situations. } \\
\hline Sign or Symptom & Qualifier \\
\hline Difficulty of breathing & RR/min \\
Pain & $+10 / 10$ \\
Bipedal edema & to ++++ \\
Cough, nausea, dizziness & Less or more \\
Capillary blood sugar & $\mathrm{mg} / \mathrm{dL}$ \\
Anemia & Hgb, Hct \\
Infection & WBC \\
Fever & Temperature \\
Jaundice & + to,++++ less or more \\
Blood pressure & Systolic and diastolic in $\mathrm{mmHg}$
\end{tabular}

between the health care provider and any other health professional contributing to the patient's care, and assisting in protecting the legal interest of the patient and the health care providers. It is a document utilized to communicate with colleagues and the health care team, the essentials of our patients' medical issues to help everyone provide the best care to the patient. It is simply a snapshot of what transpired during a patient's visit to a doctor.

Briefly, writing the progress notes follows a specific pattern:

- It has S-O-A-P parts. $\boldsymbol{S}$ for subjective data, $\boldsymbol{O}$ for objective data, $\boldsymbol{A}$ for Assessment, and $\boldsymbol{P}$ for plan

- Subjective Data changes according to whether the patient improves or worsens.

- The results of the work-up go into the Objective Data. See Figure 1. 


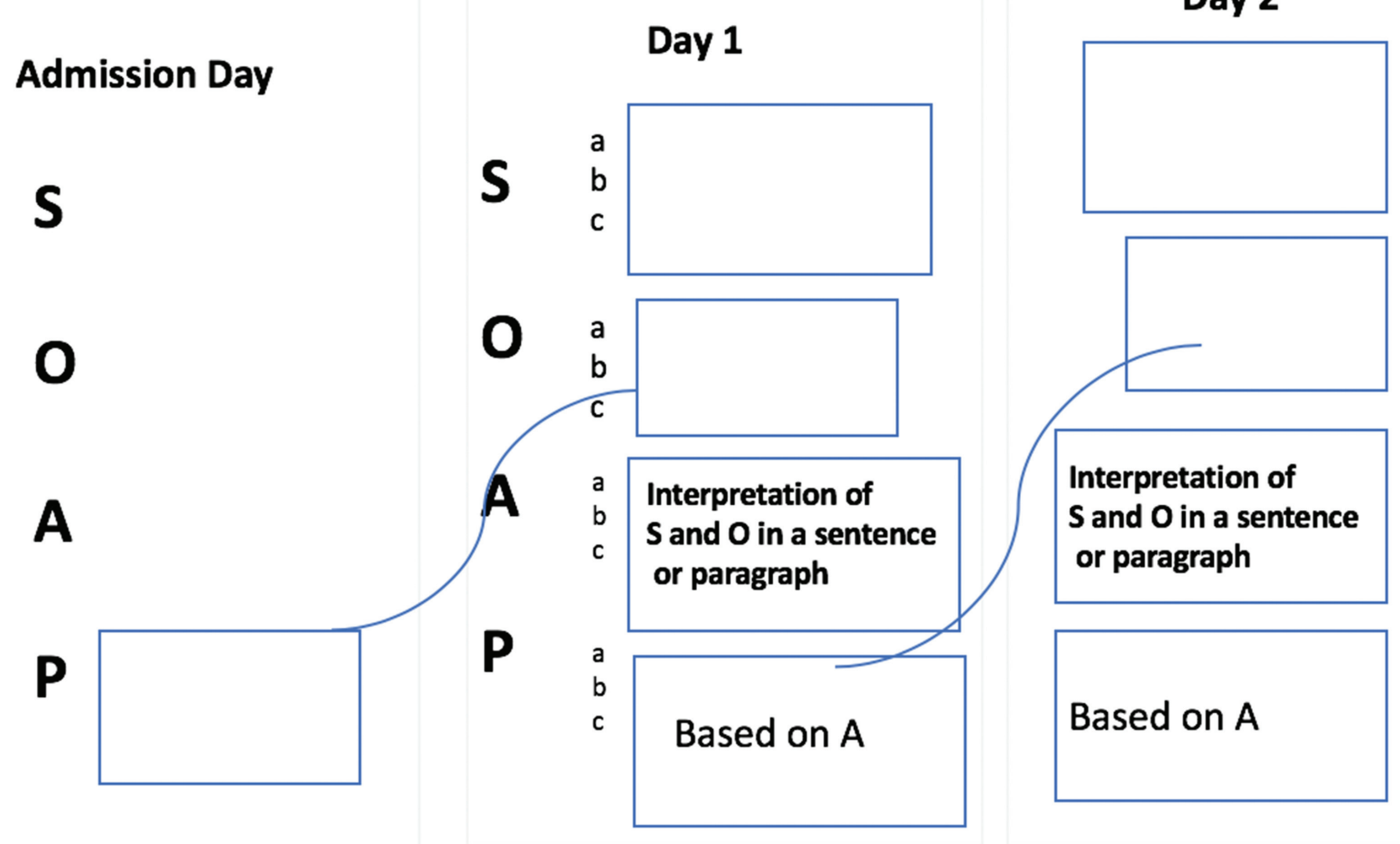

Figure 1. Mapping scheme for writing progress notes.

\section{How to Formulate Assessment}

The dizziness decreased and patient is less nauseous because the patient was hydrated and was placed on NPO. The pallor of the patient was resolved because of the blood transfusion given and the bleeding stopped. Compared to yesterday, hemoglobin is higher and normalized, BP is lower but not at goal because the blood transfusion was enough to normalize the hemoglobin and the medication for BP is not optimum, respectively. Overall the clinical status of the patient has improved and is stable.

Figure 2. Sample of Assessment.

- The changes in the physical examination findings also go into the Objective Data.

- The combined data in the $S$ and $O$ are the basis for the Assessment.

\section{WRITING THE ASSESSMENT}

Writing the Assessment follows a certain format: 1) Comparing data from yesterday's condition, 2) Giving the reason for the change, and 3) Prognostication of the patient's condition, whether improving, stable, or worsening. The Assessment is the basis for the Plan. The Plan may remain the same or needs to be revised (Figure 2).

The Assessment is written in a paragraph form. Address all changes (signs, symptoms, physical examination findings) in the subjective and objective data with, more importantly, explanation of either the improvement or worsening of each clinical feature based on the management given.

Based on the Assessment above, understandably, in the Plans, the antihypertensive medication of the patient will be adjusted. 


\section{THE TOCSE TABLE}

The TOCSE Table has the following attributes (Table 2):

- The TOCSE table is a summary of the patient's clinical course.

- It clearly depicts the resolution of acute problems of the patient.

- It shows a correlation of the course of acute problems with appropriate management.
- It shows how the target outcome is achieved.

- Data must come from daily progress notes.

- The TOCSE table has the following parts: clinical, biochemical/laboratory, imaging, if any, and treatment.

- Any new clinical problem is added accordingly.

CBG; capillary blood glucose, WBC; white blood cell count, OD, once a day, BID, twice a day, SC, subcutaneous

Table 2. Sample of a TOCSE table.

\begin{tabular}{|c|c|c|c|c|c|c|c|}
\hline Problem & Target & Admission & Day 1 & Day 2 & $\begin{array}{c}\text { Discharge } \\
\text { Day }\end{array}$ & Prescription & $\begin{array}{c}\text { OPD } \\
\text { Plan } \\
\text { (exact } \\
\text { follow- } \\
\text { up } \\
\text { date) }\end{array}$ \\
\hline \multicolumn{8}{|l|}{ A. Clinical: } \\
\hline Jaundice & $(-)$ & +++ & ++ & ++ & + & & \\
\hline $\begin{array}{l}\text { Abdominal } \\
\text { pain }\end{array}$ & $0 / 10$ & $8 / 10$ & $6 / 10$ & $3 / 10$ & $0 / 10$ & & \\
\hline Pyuria & $(-)$ & ++++ & & ++ & $(-)$ & & \\
\hline $\begin{array}{l}\text { High blood } \\
\text { pressure }\end{array}$ & $120 / 70$ & $150 / 100$ & $140 / 80$ & $130 / 70$ & $130 / 70$ & & \\
\hline $\begin{array}{l}\text { CBG } 2 \text { hours } \\
\text { post-meal }\end{array}$ & $\begin{array}{l}140- \\
180\end{array}$ & 310 & 270 & 188 & 149 & & \\
\hline \multicolumn{8}{|l|}{$\begin{array}{l}\text { B. } \\
\text { Biochemical/ } \\
\text { Laboratory }\end{array}$} \\
\hline WBC & & 23,000 & & & & & \\
\hline \multicolumn{8}{|l|}{$\begin{array}{l}\text { C. Imaging } \\
\text { Chest x-ray }\end{array}$} \\
\hline $\begin{array}{l}\text { D. } \\
\text { Treatment }\end{array}$ & & $\begin{array}{l}\text { Ciprofloxacin } \\
500 \text { mg BID } \\
\text { Amlodipine } \\
5 \text { mg OD } \\
\text { Glargine } 14 \\
\text { units daily }\end{array}$ & $\begin{array}{l}\text { Continue } \\
\text { meds }\end{array}$ & $\begin{array}{l}\text { Continue } \\
\text { meds }\end{array}$ & & $\begin{array}{l}\text { Ciprofloxacin } \\
500 \text { mg BID x } \\
7 \text { days } \\
\text { Amlodipine } \\
5 \text { mg OD } \\
\text { Glargine } 14 \\
\text { SC units } \\
\text { daily }\end{array}$ & $\begin{array}{l}\text { Repeat } \\
\text { CBC }\end{array}$ \\
\hline
\end{tabular}




\section{Discharge Summary}

On admission patient was febrile with cough, BP of 150/100, with crackles. Fever and cough resolved on $3^{\text {rd }}$ hospital day after initiation of antibiotic treatment. Blood pressure control at $130 / 80$ was noted on $2^{\text {nd }}$ hospital day with optimum dose of amlodipine. Goal of capillary blood sugar 2 hours after meal was achieved on $3^{\text {rd }}$ hospital day with glargine administration. The patient was discharged improved on $5^{\text {th }}$ hospital day.

Figure 3. Sample of Discharge Summary.

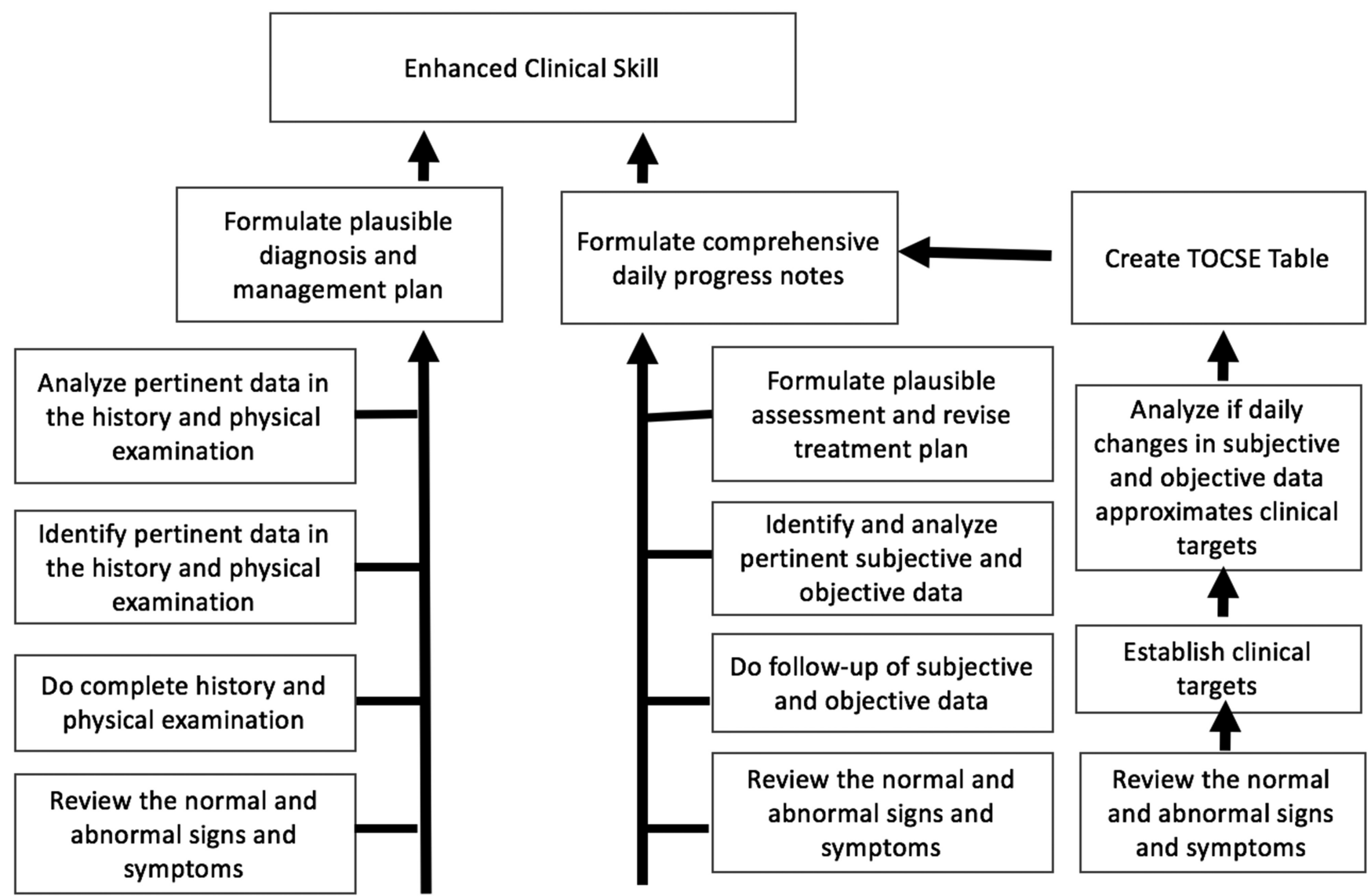

Figure 4. Concept map of Target-Oriented Clinical Skill Enhancement (TOCSE).

\section{WRITING THE DISCHARGE SUMMARY}

The Discharge Summary becomes short and brief because details are depicted in the TOCSE Table (Figure 3). It is ideal that the Discharge Summary and the TOCSE Table are given together to the patient upon discharge.

\section{SUMMARY}

The ultimate objective of TOCSE is to further develop and enhance the clinical skills of the students through understanding and application of knowledge on basic sciences like physiology, pharmacology, biochemistry, pathology, anatomy and pharmacology on signs and symptoms of the patient and hence bridging the gap to clinical application. This skill results in the ability to formulate a plausible diagnosis and comprehensive, practical and cost-effective management plan and eventual resolution of each targeted clinical problem. Figure 4 summarizes the whole concept of TOCSE.

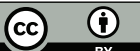

Open Access This article is licensed under a Creative Commons Attribution 4.0 International License, which permits use, sharing, adaptation, distribution 
and reproduction in any medium or format, as long as you give appropriate credit to the original author(s) and the source, provide a link to the Creative Commons license, and indicate if changes were made. The images or other third party material in this article are included in the article's Creative Commons license, unless indicated otherwise in a credit line to the material.
If material is not included in the article's Creative Commons license and your intended use is not permitted by statutory regulation or exceeds the permitted use, you will need to obtain permission directly from the copyright holder. To view a copy of this license, visit http://creativecommons.org/licenses/ by/4.0/. 